\title{
BEACH FILL AND SEDIMENT TRAP AT CAROLINA BEACH, NORTH CAROLINA
}

US Army Corps of Engineers
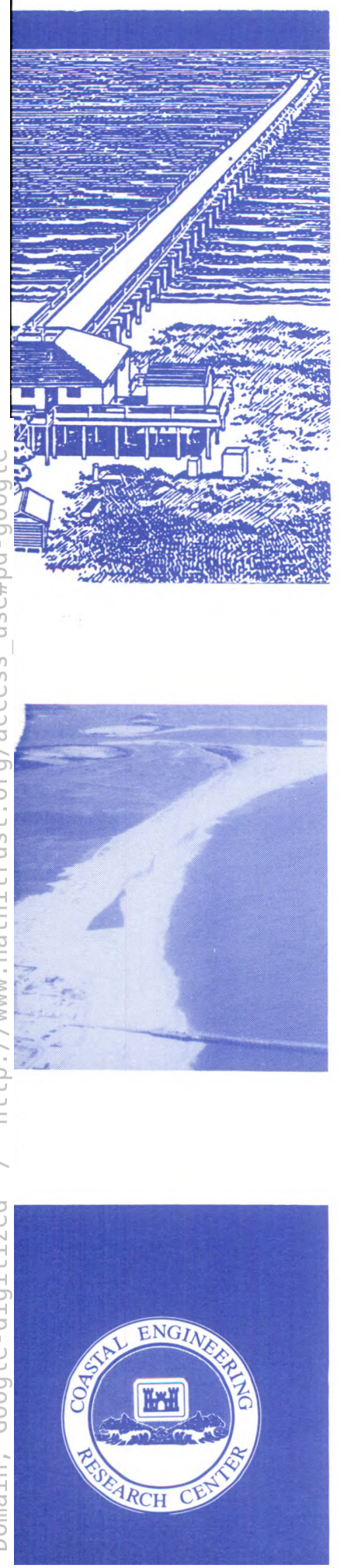

by

\section{J. Thomas Jarrett}

DEPARTMENT OF THE ARMY

US Army Engineer District, Wilmington

PO Box 1890, Wilmington, North Carolina 28042-1890 and

J. Michael Hemsley

Coastal Engineering Research Center

DEPARTMENT OF THE ARMY

Waterways Experiment Station, Corps of Engineers PO Box 631, Vicksburg, Mississippi 39180-0631
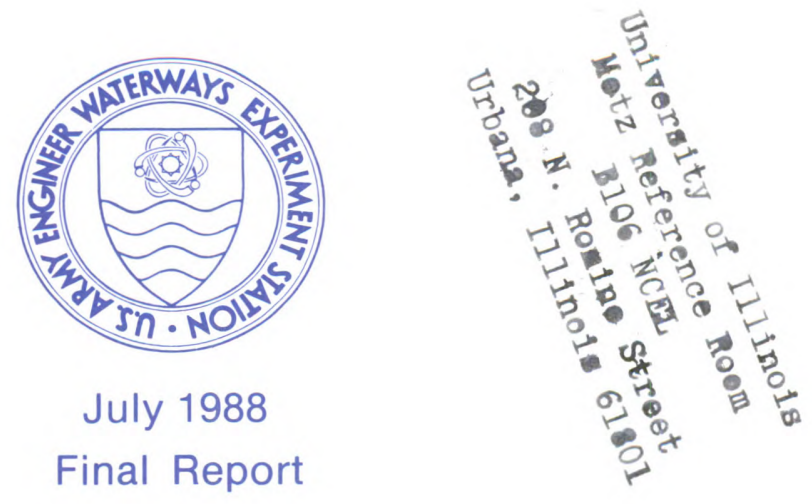

Approved For Public Release; Distribution Unlimited

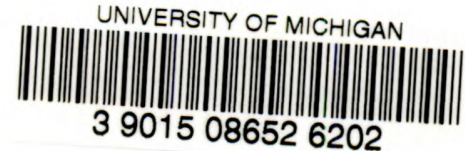

Prepared for DEPARTMENT OF THE ARMY

US Army Corps of Engineers

Washington, DC 20314-1000 